\title{
Metaphors and Destination Image in Sumedang Tourism Promotion through Social Media
}

\author{
Utama Dewi \\ Department of Linguistics Faculty of Humanities, Universitas Padjadjaran, INDONESIA \\ utamadewi86@gmail.com
}

\begin{abstract}
Many researchers do study in language tourism especially on metaphor, but it is very limited research in tourism promotion especially in Sumedang. Sumedang is part of Jawa Barat province which has many tourism potency like nature tourism, art and culture tourism, religion tourism and culinary tourism. This study tries to figure out the characteristic of language and types of metaphors found in tourism promotion texts and to explore the role of destination image in connection to tourists' choice of destination in tourism promotion through social media. The method applied on this study was descriptive method. The data were taken from Sumedang tourism promotion texts in social media. The classification of the data refers to Newmark's metaphor classification. Result shows that standard metaphor is the dominant metaphor found in data, followed by dead metaphor, and cliche metaphor as the least used in Sumedang tourism promotion in social media. Besides, the use of destination image in tourism promotion through social media has important role and big impact to attract tourist to visit the tourism object and enjoy the tourism product.
\end{abstract}

Keywords: Metaphor, destination image, sumedang tourism promotion, social media

\section{INTRODUCTION}

Tourism is one the most important industries of the world economy, having a great contribution to economic development. Promotion of tourism destinations has a vital role and can be held by advertisement in any other media such as internet, television, radio, newspapers, magazines, brochures, even from friends or relatives who had already visited the place.

As a process of communication, advertising is represented as a continuum of text functions, fluctuating between informing, and manipulating. In this respect, advertisements should inform, persuade, and induce action (encourage people to purchase the product advertised). In order to influence choices, advertising tries to demonstrate the uniqueness of their product and to constantly stimulate the desire to travel into different places. Language is a great power for advertising, it uses different linguistic techniques at different levels to be persuasive and seductive, such as phonetics, lexis and morphology, semantics and pragmatics.

Metaphor is one of figurative languages which is usually used to compare or to draw an analogy of something to another one or the general things to special ones. Metaphor is defined as a linguistic expression whose meaning cannot be reached directly from the emblem used, because the meaning is contained in the prediction that linguistic expression. As in illustration, it is an example "My love is love is a flower" suggest delicacy and beauty. "The king of the jungle" refers to "a lion" that supposed to have the most authority and strongest than animals live in the jungle. As Lakoff and Johnson (1980:1) stated "...that metaphor is pervasive in everyday life not just in language but in thought and action".

By using metaphors (or language) in tourism destination promotion texts, the writer tries to persuade readers (or tourists) to visit such destination places. Many researchers found that metaphor is effective in promotion. Beside metaphor (or language) has the important role, destination image also plays significant role in connection with tourists' choice of destination. Generally speaking, the destination image influences the potential tourist's subjective perception and consequent behavior and destination choice. If the image is carefully positioned in the minds of potential tourists, it will evoke unique emotions that will differentiate the destination from its competitors and persuade tourists to visit, and perhaps revisit, the destination. Due to the breadth of the tourism problem, this research will be limited to the study of tourism language, especially the metaphor and destination image in the promotion of tourism in Sumedang.

Sumedang is one of regencies in West Java, with the capital of the same city. Sumedang is located $45 \mathrm{~km}$ Northeast from Bandung city. This regency is bordered by Indramayu district in the North, Majalengka in East, Garut regency in the South, Bandung regency in West and Subang districts in the West. Because Sumedang located between two major cities, which is Bandung and Cirebon, the city is often known as a haven for those who were to travel overland between Bandung and Cirebon. Sumedang is known with 'Tahu Sumedang' or traditional deep fried tofu which is yummy and delicious, and it makes this tofu famous into out of Sumedang. Since Sumedang has a lot of tourism potency includes nature tourism, art and cultural tourism, historical tourism and culinary tourism, Sumedang regency is selected as the object of research.

\section{THEORETICAL FRAMEWORK 2.1. METAPHOR}

\subsubsection{DEFINITION OF METAPHOR}

Metaphor is one of the figures of speech besides simile, personification, hyperbole, and understatement. Metaphor is called a figure of speech, since metaphor is not straightforward. As Richards et al. (1989: 106) describes "In a metaphor, no function words are used. Something is described by stating another thing with which it can be compared". Lakoff and Johnson (1980: 5) defined metaphor (in their book 
"Metaphor We Live By" refers to metaphorical concept) as follow "The essence of metaphor is understanding and experiencing one kind of thing in terms of another." Since metaphor is argued as understanding and experiencing, it can be related to culture. Metaphor and culture are very close. As Kovecses (2007: 1) argued that "...metaphor and culture can be seen as intimately linked". After all, metaphor can be viewed as the ornamental use of language. Thus, metaphor and culture may be seen as being related to each other because they are combined in literature - an exemplary manifestation of culture".

\subsubsection{TYPES OF METAPHOR}

According to Newmark (1988), metaphors are divided into six types. They are dead metaphor, cliché metaphor, standard or stock metaphor, recent metaphor, original metaphor, and adapted metaphor.

\section{(1) Dead Metaphor}

Newmark argues that "Dead metaphor is metaphors where one is hardly conscious of the image, frequently relate to the universal terms of space and time, the main part of the body, general ecological features and the main human activities." In Bahasa, the examples of dead metaphor are kaki gunung 'foot of the mountain' and mata air panas 'hot spring'.

\section{(2) Cliché metaphor}

Cliche metaphor is temporarily outlived their usefulness, that are used as a substitute for clear thought, often emotively, but without corresponding to the fact of the matter." In English, the examples of cliché metaphor are the words backwater and breakthrough in the sentence The country school will in effect become not a backwater but a breakthrough.

\section{(3) Stock or standard metaphor}

Newmark (1988: 108-109) defines that:

"A stock metaphor as an established metaphor in an informal context is an efficient and concise method of covering a physical and or mental situation both referentially and pragmatically - a stock metaphor has certain emotional warmth. An example of stock or standard metaphor in English is "keep the pot boiling". From the example, it is described that the pot is boiling, as we know that something which is boiled is liquid not the pot.

\section{(4) Adapted metaphor}

This metaphor is adapted from the contemporary metaphor. The example of the adapted metaphor is the ball is a little in their court, it is adapted from the contemporary metaphor the ball is in their court.

\section{(5) Recent metaphor}

It is called a metaphorical neologism.It is called neologism since the words used are new metaphors or renew themselves in language. The examples of metaphorical metaphors are walkman from the word walk and man. The metaphor has a new meaning 'portable casette player'. The metaphor software is from the word soft and ware, they make a new meaning.

\section{(6) Original metaphor}

Original metaphor contains a message, attitude or view from the writer. This metaphor is sometimes called as a poetical metaphor. It is used by the writer to express something more specific. For instance, "Presiden Stearns expressed his condolence to the victim of tsunami in Asia, "This tidal wave of generosity will help them rebuild...". He used the tidal wave as metaphor since the word tidal used to describe a generosity. The sixth type of metaphor mentioned above is used to classify the data discussed in the following chapter

\subsection{PERSONIFICATION}

Personification is one of figurative meaning which describes the object as if it could do something like humans. The use of the personification gives a description of the objects being compared as the life and able to perform the actions performed by humans or creatures to make the comparison, so as to turn the inanimate object.

\subsection{DESTINATION IMAGE}

The study of the destination image dates back to the early 1970s, when the destination image plays a central role in tourists' selection process. Today, there is a general agreement among tourism researchers and academics that a positive destination image results in increased visitation and has an impact upon tourists' evaluation and selection of destination.

\subsection{TOURISM PROMOTION IN SOCIAL MEDIA}

There are many types of promotion media. They could be printing or non-printing media. The printing media could be leaflets, brochures, booklets, billboards, or even street banners. The non-printing media could be radio advertisement, $\mathrm{TV}$, or social media. The last type, social media is now more popular than others. Some people choose to promote their product through the social media than the printing media since it would be cheaper, faster, and more attractive to some people.

People usually use metaphor in their promotion. McQuarrie and Mick (1996) mentioned that "Advertisements often make use of metaphors". The World is in your Hand is a promotion of a cellular phone. It introduces a metaphor, by using your cellphone you can communicate to people around the world. Without visiting the place where the people live, you can connect them easily, in other words, the world is in your hand. People use metaphor not only in promoting cellular phones but also promoting tourism destinations. In Bahasa Indonesia, the words "burung nirwana" or ,paradise bird" used to describe "burung Cendrawasih" or "Cendrawasih bird $^{\text {ee }}$. The bird Cendrawasih is an endemic animal from Papua. Papua is one of the Indonesia islands. It is one of tourism objects in Indonesia. Cendrawasih bird has beautiful colors of fur, so it is compared to paradise that is why the 
birds called paradise birds. Here there is a relationship between metaphor and region Sumedang. Sumedang is the one of region in Jawa Barat as called "Kota Tahu". Kota means city and tahu means tofu. To attract the tourists visit to Sumedang, people usually use "Kota Tahu" than the word 'Kota Sumedang' in their promotion media.

\section{RESEARCH METHOD}

The method used in this research is descriptive method. It is a qualitative study (Creswell, 2013). According to Nunan (1992), qualitative research assumes that all knowledge is relative, that there is a subjective element to all knowledge and research and that holistic ungeneralisable studies are justifiable. The aim of descriptive research is to describe condition and phenomenon status. Therefore, it intends to describe the phenomenon of the metaphors and its intentions contained in the promotion text.

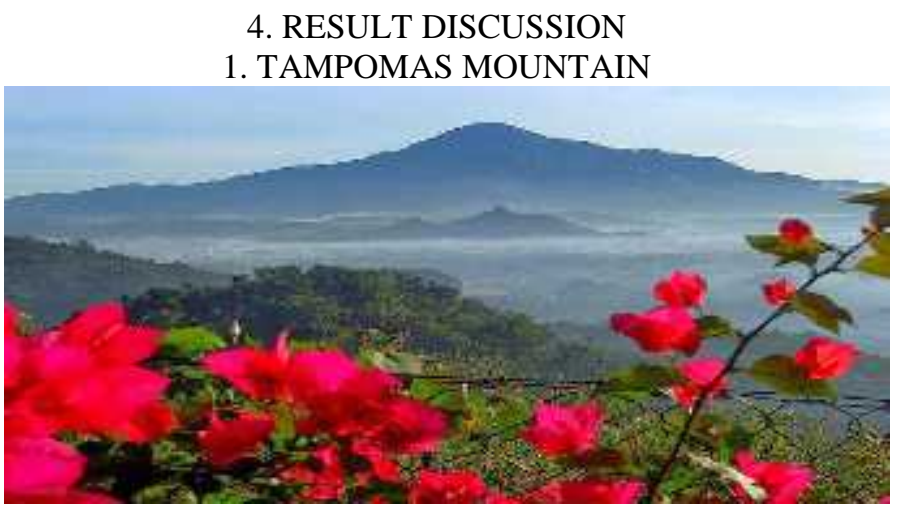

www.blogspot.com

"Selain menikmati pemandangan alamnya, kegiatan wisata lain adalah mendaki gunung, memotret, atau menikmati mata air panas di kaki gunung. Lubang kawah dan gugusan batu besar berwarna hitam, menambah keindahan alam pegunungan”.

In the Tampomas Mountain tourism promotion above, it is used some kinds of metaphor i.e the phrase 'kaki gunung' and 'mata air' which use a dead metaphor. Both of expressions which use human body parts is intended to turn the promotional messages of Tampomas mountain. Besides, the phrase 'gugusan batu besar' uses standard metaphor that describe the physical description and situation of Tampomas Mountain in order to make the tourists interested to visit this place.

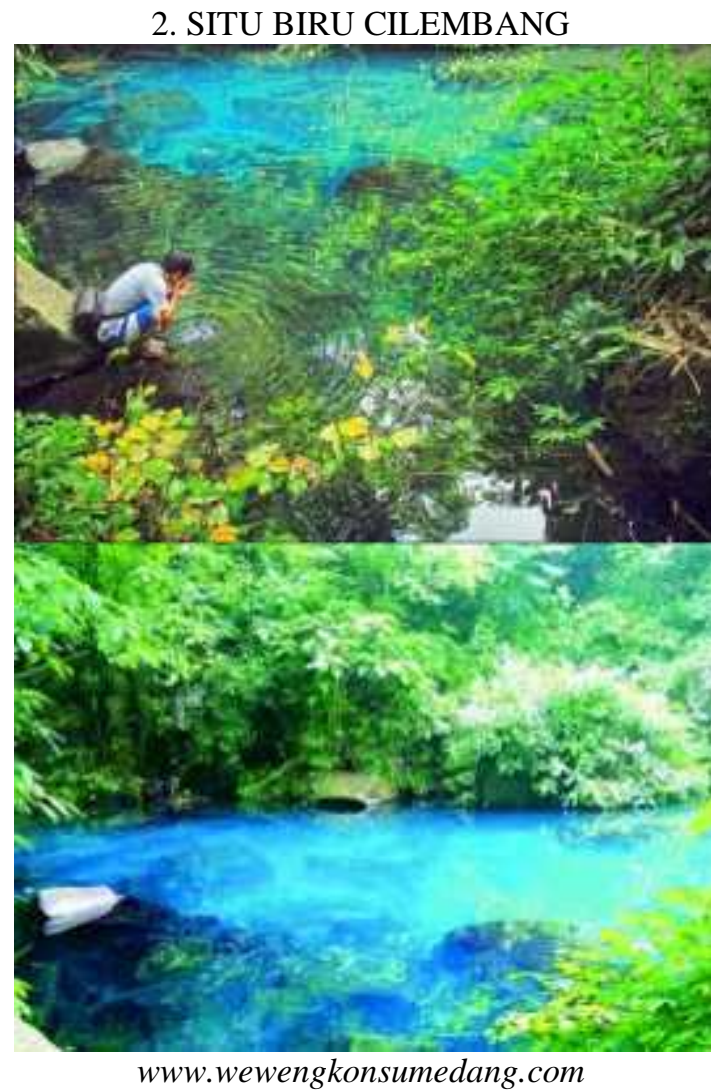

"Tempat wisata ini memiliki air yang bening dan berwarna biru yang eksotis.[...] Telaga ini menyuguhkan pemandangan yang masih alami karena memang berada di dalam hutan yang tersembunyi nan eksotis"

In the tourism promotion of Blue Lake Cilembang, there is a cliche metaphor in the phrase "hutan yang tersembunyi nan eksotis" which describe physical description and nature situation of the lake. Beside use metaphorical language, the promotion text also use the expression of personification in the sentence "Telaga ini menyuguhkan pemandangan yang masih alami" The sentence means that the tourism object can act as human that is able to 'present' something. The using of personification above tries to make alive the tourism destination.

\section{KAMPUNG TOGA}

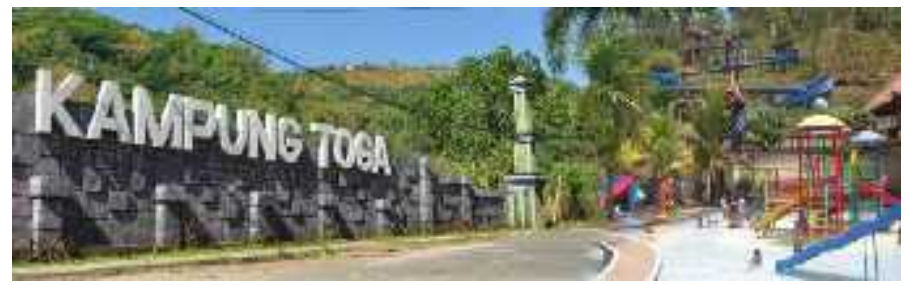

www.kampungtoga-sumedang.blogspot.com

“..........Bagi anda yang menyukai olahraga gantole atau paralayang, bisa menikmati dari ketinggian nuansa 
perbukitan yang eksotis, pemandangan kota sumedang, serta hamparan sawah dan sungai yang indah."

In this promotion text there are two expressions as standard metaphor, it is the phrase "nuansa perbukitan" and the phrase "hamparan sawah". The word 'nuansa and hamparan' is used as an emotional expression to describe the situation around the Kampung Toga tourism with a lot of hill and rice fields, therefore it makes the location around the place is very beautiful.

\section{CURUG SINDULANG}

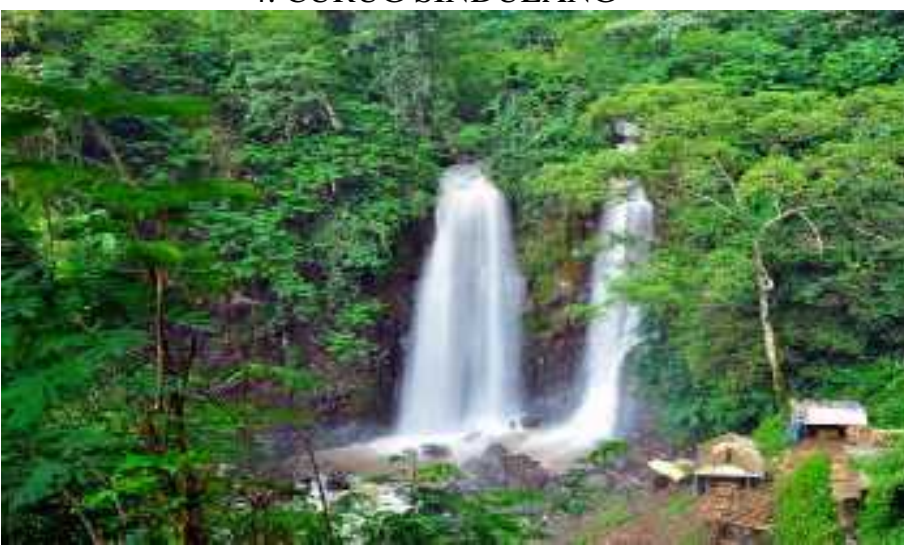

www.sinarpaginews.com

"Curug Sindulang yang romantis ini, juga dikenal sebagai air terjun kembar. Dengan pemandangan wisata alam yang aduhai serta karakteristik unik, tempat wisata ini menjadi buruan para pecinta wisata pegunungan. Anda bisa merasakan ketenangan hutan yang romantis".

There are two personification expression in this promotion text. The first expression is "wisata alam yang aduhai", the word 'aduhai' usually use for term beauty people especially for woman. And then the phrase "hutan yang romantis" means that the tourism object can act as human that is able to close with the forest.

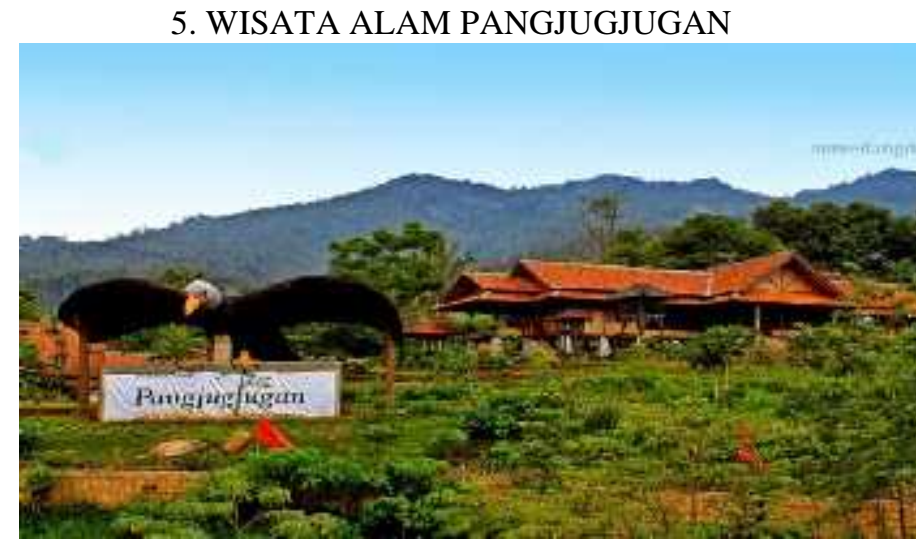

Desa Wisata Alam Pangjugjugan via www.sgdnews.com

"Sebagai desa agrobisnis dan agrowisata, tempat ini sangat eksotis untuk bercengkrama dengan alam, mendengar desau pohon pinus, gemericik air dan gemulai ikan, hingga elang yang menari indah di udara”.

In the promotion text of nature tourism Pangjugjugan, almost the expressions are used personification. The first phrase is "bercengkrama dengan alam". The word "bercengkrama" usually means the object can act as human, it means close with the nature. Same with another expression, "desau pohon", "gemulai ikan" and then "elang yang menari" is the expressions which means act as human. All of the expression is an emotional expression to describe the circumstances and situations around and invite curiosity of the tourists in order to visit those tourism objects.

Previously not many know that Sumedang has a lot of potential for tourism. But today along with technology advanced through social media internet, Sumedang known as small town that has many tourism product i.e nature tourism, art and culture tourism, religion tourism, culinary tourism and others. There are many ways to improve the number of tourists in order to visit to Sumedang. One of them is by giving information through advertisement or promotion in social media because it's media is cheaper, faster, and more attractive to some people.

In addition destination image in tourism promotion also has the central role to improve the number of tourist. For that case, the example is "the blue lake Cilembang". This blue lake is the new tourism destination which many visitors come from local and foreign. Most of them say that they know about Situ Biru Cilembang is from internet media. They attracted to visit the place because the information and picture in the promotion are very interesting and make them curiosity to visit the place.

\section{CONCLUSION}

The results of this research show that the types of metaphor often employed are stock or standard metaphor, dead metaphor, and cliche metaphor. The use of Standard metaphor attached to the physical condition of the tourism object, such as the phrase 'hamparan sawah', 'gugusan batu' and the phrase 'nuansa perbukitan' which shows the panoramic beauty of the destinations being promoted. The second metaphor often employed is dead metaphor. the use of dead metaphor is always associated with the type of tourist objects such as the word 'kaki gunung' and 'mata air' which uses human body parts is intended to turn the promotional messages of tourism object. The third metaphor employed is cliche metaphor, such as the phrase 'tersembunyi nan eksotis' which describe physical description and nature situation of the tourism object.

Therefore beside metaphor, there are many expressions of personification in Sumedang tourism promotion texts, they are the phrase 'menyuguhkan pemandangan', 'hutan yang romantis', 'wisata alam yang aduhai', 'bercengkrama dengan alam', "suara desau pinus', "gemulai ikan", and the phrase "elang yang menari" is the expression which has a deeper and more alive meaning as if the tourism objects are able to act like a human. Personification uses living creature as the imagery of tourism object. Therefore, the tourism object is 
identically described as human to make the tourists interested to visit.

Since destination image plays a central role in tourists' selection process and social media has become popular media to promote tourism, so destination image in tourism promotion through social media has the important role and big impact to attract tourist to visit the tourism object and enjoy the tourism product.

\section{REFERENCES}

Creswell, J. W. (2013). Desain Penelitian: Pendekatan Kualitatif, Kuantitatif dan Campuran. Terjemahan Achmad Fawaid. Yogyakarta: Pustaka Pelajar

Lakoff, G. \& Johnson, M. (1980). Metaphors We Live by. Chicago: The University of Chicago Press.

Richards, J., Platt, J., \& Weber, H. (1989). Longman Dictionary of Applied Linguistics. London: Longman.

Kovecses, Z. (2007). Metaphor and Emotion. New york: Cambridge university Press.

McQuarrie, E. F., \& Mick, D.G. (1996). Figures of Rhetoric in Advertising Language. Journal of Consumer Research 424-438.

Newmark, P. (1988). A Textbook of Translation. Singapore: Prentice Hall.

Nunan, D. (1992). Research Methods in Language Learning. Cambridge: CUP. 